\title{
HIGHLIGHT
}

\section{Insulin begets insulin}

\author{
Mehboob A Hussain \\ Laboratory of Molecular Endocrinology, Howard Hughes Medical Institute, Massachusetts General Hospital, 50 Blossom Street Wellman 320, Boston, \\ Massachusetts 02114, USA
}

The pathogenesis of type 2 diabetes is characterized by insulin resistance, primarily in skeletal muscle, fat and liver, and a relative failure of the pancreatic $\beta$-cell $(1,2)$. Considerable controversy surrounds the issue of which of these deficiencies is the primary cause of diabetes. In some studies, the earliest observed defect is dysfunctional secretion and in others insulin resistance appears to be the first detectable problem. Some important new studies open a new perspective to these questions.

Glucose is the principal regulator of insulin secretion from pancreatic $\beta$-cells. Insulin is secreted immediately in response to elevated glucose concentrations. After insulin secretion, an immediate response takes place within the $\beta$-cell to replenish insulin stores through activation of insulin biosynthesis at the transcriptional (3) as well as translational levels $(4,5)$. The signals that govern the signal transduction pathway that link the glucose stimulus to the initiation of insulin gene transcription have been largely unclear. Intraislet interactions as well as extrapancreatic hormones and neural inputs exert an important level of control over insulin synthesis and secretion and ultimately glucose homeostasis. Several lines of evidence support the possibility of an autocrine action of insulin on $\beta$-cells. Insulin binds to the surface of $\beta$-cells $(6,7)$, and functional insulin receptors and insulin receptor substrates (IRSs) identical to those found in peripheral tissues have been identified in both clonal and primary $\beta$-cells $(6,8,9)$. Glucose stimulation of $\beta$-cell lines activates the $\beta$-cell insulin receptor much in the same way as application of exogenous insulin, suggesting that insulin secreted from $\beta$-cells binds to the insulin receptor eliciting a physiological response (10). The complete physiological consequences of insulin receptor activation of the $\beta$-cell have yet to be completely elucidated, but at least one effect is initiation of protein synthesis at both transcriptional and translational levels (11).

However, there remains controversy on the effects of insulin on $\beta$-cell secretion. Several reports have shown that glucose-stimulated insulin or C-peptide secretion from islets or perfused pancreas is suppressed in the presence of exogenous insulin, leading to the concept of a negative feedback of insulin secretion by insulin (12-18). Under similar conditions, however, other investigators have found little or no effect of insulin on glucose-stimulated insulin secretion (1921). Furthermore, these data have been difficult to interpret because of neuronal and intraislet hormonal regulatory mechanisms that could interact with exogenous insulin, and the use of high glucose levels in these studies could per se evoke the effects of substantial stimulation of the $\beta$-cell insulin receptors masking the effect of exogenous insulin.

Experiments with purified $\beta$-cells have also generated conflicting evidence for insulin feedback. Glucosestimulated insulin secretion from purified $\beta$-cell lines is inhibited by exogenous insulin levels $(1 \mu \mathrm{mol} / \mathrm{l})(21)$. In contrast, measurements of the effect of insulin on $C$-peptide secretion in $\beta$ TC 3 cells failed to show direct evidence of secretory regulation by insulin. Furthermore, transfected $\beta$ TC6-F7 cells in which the insulin receptor was overexpressed showed enhanced basal and glucose-stimulated insulin secretion, but fractional secretory levels remained unchanged at all glucose concentrations whereas cells expressing kinase negative (inactive) insulin receptors showed decreased glucosestimulated insulin secretion (11). These results suggest an autocrine pathway regulating one or more of the following: insulin secretion, insulin synthesis, and glucose sensing/utilization.

Several studies have revisited the question on whether insulin may have an autocrine effect on insulin synthesis and secretion.

Leibiger et al. (22) studied the effects on insulin gene transcription of depolarization of $\beta$-cells by adding (i) glucose, (ii) $\mathrm{KCl}$, or (iii) sulfonylureas to the culture medium. The depolarization, which takes place in all three cases and induces insulin secretion, was also accompanied by an increase in insulin gene transcription as assessed by reverse transcription PCR and by transfected insulin-promoter-green fluorescent protein reporter constructs. By adding various pharmacological inhibitors of the signal transduction pathway, the investigators delineated two pathways leading to an increased insulin gene transcription rate: the PI-3 kinase/p70 s6 and the CaM kinase II. Furthermore, stimulation of hamster insulinoma (HIT) cells with glucose or insulin led to increased PI-3 kinase activity in immunoprecipitates obtained with anti-IRS-2 antibodies. These same pathways are also involved in insulin receptor signal transduction. Thus the investigators studied the effect of overexpression of type A and $B$ insulin receptors in HIT cells and found that the overexpression of type A led to an enhanced insulin 
transcription response upon glucose stimulus. Moreover, the authors mutated several critical sites within the insulin promoter and then studied the effects of extracellular stimuli on insulin gene transcription. The elements within the insulin gene promoter found to be critical for insulin-stimulated insulin transcription are DNA binding sites for $\beta$-cell-specific transcription factor PDX-1 $(23,24)$.

Aspinwall et al. (25) reported that in isolated murine, human, canine and porcine $\beta$-cells exogenous insulin elicited a secretory response, which was measured by a sophisticated amperometric measurement. For these assays, microelectrodes were positioned approximately $1 \mu \mathrm{m}$ from a cell and stimulant was applied from a micropipette approximately $30 \mu \mathrm{m}$ from the cell. When secretion by vesicle fusion occurs, a current spike is recorded and corresponds to quantitative detection of molecules released by exocytosis. In their studies they demonstrated that immunoneutralization of insulin could prevent the measured secretory response. Furthermore, the effect of exogenous insulin was also abolished in the presence of anti-insulin receptor antibody, confirming that the insulin receptor on $\beta$-cells is required for the secretory response. To test the possibility of direct autocrine actions of insulin, single $\beta$-cells were stimulated with potassium in the presence and absence of anti-insulin receptor antiserum. The results indicate that addition of antibody blocked the released insulin from further enhancing insulin release. Furthermore, there was a (nonsignificant) tendency towards a glucose concentration dependency of insulin-stimulated insulin release. The effects of insulin were not accompanied by depolarization of the $\beta$-cells, and insulin-stimulated secretion was not dependent upon extracellular calcium.

A remarkable in vivo study has been performed by Kulkarni et al. (26), who have generated mice with a tissue-specific knockout of the insulin receptor in pancreatic $\beta$-cells. In these $\beta$-cell insulin receptor knockout ( $\beta$ IRKO) mice, several features of type 2 diabetes mellitus are found. No significant changes in random baseline glucose levels were detectable in 2- or 6-month-old mice. However, a mild fasting hyperinsulinemia was detectable at 6 months of age in both male and female mice. When the mice were challenged with a glucose load, a clear change in insulin secretory response was found. In control littermates, a 3- to 4fold increase in circulating insulin levels was observed 2 min after an i.p. application of glucose, with elevated insulin levels up to $30 \mathrm{~min}$ after glucose injection. In contrast, in the $\beta$ IRKO animals the acute insulin response to glucose was absent (male mice) or severely blunted (female mice), and a slow increase of insulin levels followed until at $30 \mathrm{~min}$ the insulin levels were comparable with those of the control animals. This observation is most likely due to a disturbed first phase insulin response to glucose while the second phase appears to be intact. An arginine challenge, a second insulin secretagogue, was unaltered in the $\beta$ IRKO mice, thus suggesting that the $\beta$-cell dysfunction in $\beta$ IRKO animals is specific to glucose, and that a functional insulin receptor is a prerequisite for the normal glucosestimulated insulin secretion.

Glucose tolerance, as assessed by i.p. glucose loading, was already impaired in $\beta$ IRKO animals at 2 months and continued to deteriorate as their age advanced. This was accompanied by reduced insulin levels throughout a glucose tolerance test.

Morphologically the islets appeared normal at 2 months of age in all mice. At 4 months there appeared to be a $20-40 \%$ reduction in islet size in the $\beta$ IRKO mice. Whole pancreatic insulin content, as measured by RIA, was significantly reduced by about $35 \%$ in the $\beta$ IRKO animals at 4 months of age. Glucose transporter 2 (GLUT2) immunoreactivity in pancreatic $\beta$-cells appeared unchanged in the $\beta$ IRKO animals. In summary, these $\beta$ IRKO animals exhibit an age-dependent progressive impairment in their ability to dispose of a glucose load. It would be nice to know whether, in these mice, the defect in insulin secretion from the pancreatic $\beta$-cell per se causes peripheral insulin resistance.

The studies make it clear that the effects of insulin are required for a normal function of the pancreatic $\beta$-cell. There are other factors such as neuronal inputs, incretins, free fatty acids, still unknown agents, and of course glucose which are required for the normal, physiological insulin secretory response.

The existence of a positive feedback of insulin on insulin secretion may allow the explanation of several phenomena in $\beta$-cells. Insulin secretion from islets has been demonstrated to be oscillatory in nature, and many models of oscillation have assumed some form of positive feedback by a diffusible factor released from $\beta$-cells (27-29). No compound has been satisfactorily identified that could serve this role. The results of the present studies indicate insulin as a possible candidate. Oscillations in insulin release are of significant interest because loss of oscillatory release is an early symptom of type 2 diabetes mellitus (30). Finally, it has been demonstrated that many type 2 diabetics have a marked reduction in first phase insulin secretion (just as the $\beta$ IRKO mice) (31).

The observation that insulin receptors on $\beta$-cells mediate insulin secretion and synthesis, in addition to the well known role of activating peripheral glucose utilization, leads to the possibility of a direct link between dysfunctional insulin secretion and insulin resistance. It is now conceivable that either secretion of insulin from $\beta$-cells or insulin resistance at the $\beta$-cell level may be the first pathogenic disturbance in type 2 diabetes.

Since it is recognized that type 2 diabetes mellitus is a genetic disorder, the answer most likely lies in a collusion of several genetic variations and/or mutations. Additionally, the questions are raised whether agents such as the incretin glucagon-like peptide-I, the growth factor insulin-like growth factor-I, or other 


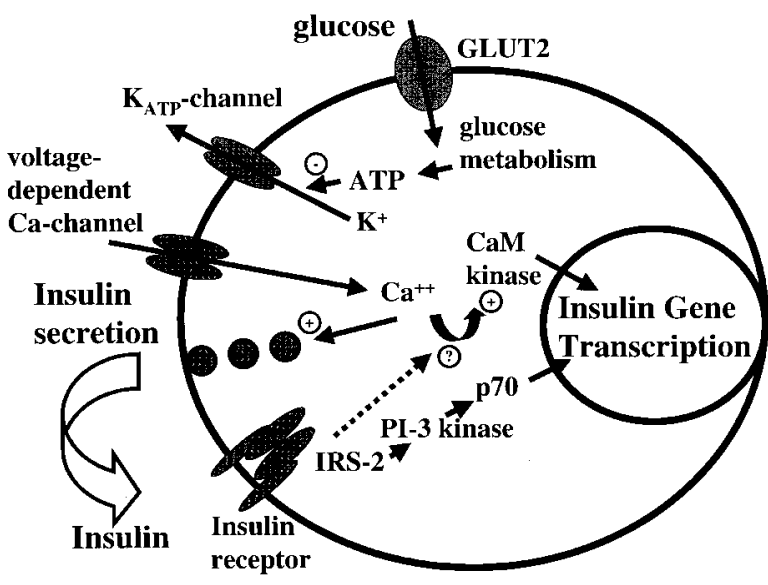

Figure 1 Coupling of insulin secretion (extracellular insulin) with insulin gene transcription. Additionally insulin appears to have a positive effect on insulin secretion, hypothetically by increasing intracellular calcium induced by pathways downstream of the insulin receptor.

agents can partially ameliorate $\beta$-cell function if the signaling through the insulin receptor deteriorates.

\section{Acknowledgements}

$\mathrm{MAH}$ is a recipient of a Juvenile Diabetes Foundation International Career Development Award.

\section{References}

1 Martin BC, Warram JH, Krolewski AS, Bergman RN, Soeldner JS \& Kahn CR. Role of glucose and insulin resistance in development of type II diabetes mellitus: results of a 25-year follow-up study. Lancet $1992340925-929$.

2 Lillioja S, Mott DM, Spraul M, Ferraro R, Foley JE, Ravussin E et al. Insulin resistance and insulin secretory dysfunction as precursors of non-insulin-dependent diabetes mellitus: prospective studies of Pima Indians. New England Journal of Medicine 1993329 1988-1992.

3 Efrat S, Surana M \& Fleischer N. Glucose induces insulin gene transcription in a murine pancreatic beta-cell line. Journal of Biological Chemistry 1991266 11141-11143.

4 Gilligan M, Welsh GI, Flynn A, Bujalska I, Diggle TA, Denton RM et al. Glucose stimulates the activity of the guanine nucleotideexchange factor eIF-2B in isolated rat islets of Langerhans. Journal of Biological Chemistry $19962712121-2125$.

5 Welsh M, Nielsen DA, MacKrell AJ \& Steiner DF. Control of insulin gene expression in pancreatic beta-cells and in an insulinproducing cell line, RIN-5F cells. II. Regulation of insulin mRNA stability. Journal of Biological Chemistry 1985260 13590-13594.

6 Verspohl EJ \& Ammon HP. Evidence for presence of insulin receptors in rat islets of Langerhans. Journal of Clinical Investigation 198065 1230-1237.

7 Patel YC, Amherdt M \& Orci L. Quantitative electron microscopic autoradiography of insulin, glucagon, and somatostatin binding sites on islets. Science 1982217 1155-1156.

8 Gazzano H, Halban P, Prentki M, Ballotti R, Brandenburg D, Fehlmann $\mathrm{M}$ et al. Identification of functional insulin receptors on membranes from an insulin-producing cell line (RINm5F). Biochemical Journal $1985226867-872$.

9 Harbeck MC, Louie DC, Howland J, Wolf BA \& Rothenberg PL. Expression of insulin receptor mRNA and insulin receptor substrate 1 in pancreatic islet beta-cells. Diabetes 199645 711-717.
$10 \mathrm{Xu} \mathrm{G}$, Howland J \& Rothenberg PL. Insulin and secretagogues differentially regulate fluid-phase pinocytosis in insulin-secreting beta-cells. Biochemical Journal 1996318 623-629.

$11 \mathrm{Xu}$ GG \& Rothenberg PL. Insulin receptor signaling in the beta-cell influences insulin gene expression and insulin content: evidence for autocrine beta-cell regulation. Diabetes 199847 1243-1252.

12 Ammon HP, Reiber C \& Verspohl EJ. Indirect evidence for shortloop negative feedback of insulin secretion in the rat. Journal of Endocrinology 1991128 27-34.

13 Argoud GM, Schade DS \& Eaton RP. Insulin suppresses its own secretion in vivo. Diabetes $198736959-962$.

14 Draznin B, Goodman M, Leitner JW \& Sussman KE. Feedback inhibition of insulin on insulin secretion in isolated pancreatic islets. Endocrinology 1986118 1054-1058.

15 Iversen J \& Miles DW. Evidence for a feedback inhibition of insulin on insulin secretion in the isolated, perfused canine pancreas. Diabetes $1971201-9$.

16 Liljenquist JE, Horwitz DL, Jennings AS, Chiasson JL, Keller U \& Rubenstein AH. Inhibition of insulin secretion by exogenous insulin in normal man as demonstrated by C-peptide assay. Diabetes 197827 563-570.

17 Loreti L, Dunbar JC, Chen S \& Foa PP. The autoregulation of insulin secretion in the isolated pancreatic islets of lean (obOb) and obesehyperglycemic (obob) mice. Diabetologia 197410 309-315.

18 Pace CS, Matschinsky FM, Lacy PE \& Conant S. Electrophysiological evidence for the autoregulation of beta-cell secretion by insulin. Biochimica et Biophysica Acta 1977497 408-414.

19 Luzi L, Battezzati A, Perseghin G, Bianchi E, Vergani S, Secchi A et al. Lack of feedback inhibition of insulin secretion in denervated human pancreas. Diabetes 199241 1632-1639.

20 Schatz H \& Pfeiffer EF. Release of immunoreactive and radioactively prelabelled endogenous (pro)-insulin from isolated islets of rat pancreas in the presence of exogenous insulin. Journal of Endocrinology 197774 243-249.

21 Van Schravendijk CF, Heylen L, Van den Brande JL \& Pipeleers DG. Direct effect of insulin and insulin-like growth factor-I on the secretory activity of rat pancreatic beta cells. Diabetologia 199033 649-653.

22 Leibiger IB, Leibiger B, Moede T \& Berggren PO. Exocytosis of insulin promotes insulin gene transcription via the insulin receptor/PI-3 kinase/p70 s6 kinase and CaM kinase pathways. Molecular Cell 19981 933-938.

23 Sharma A \& Stein R. Glucose-induced transcription of the insulin gene is mediated by factors required for beta-cell-type-specific expression. Molecular and Cellular Biology 199414 871-879.

24 Docherty K \& Clark AR. Nutrient regulation of insulin gene expression. FASEB Journal 19948 20-27.

25 Aspinwall CA, Lakey JR \& Kennedy RT. Insulin-stimulated insulin secretion in single pancreatic beta cells. Journal of Biological Chemistry 1999274 6360-6365.

26 Kulkarni RN, Brüning JC, Winnay JN, Postic C, Magnuson MA \& Kahn RC. Tissue-specific knockout of the insulin receptor in pancreatic $\beta$ cells creates an insulin secretory defect similar to that in type 2 diabetes. Cell 199996 329-339.

27 Bosco D, Orci L \& Meda P. Homologous but not heterologous contact increases the insulin secretion of individual pancreatic Bcells. Experimental Cell Research $198918472-80$.

28 Maes E \& Pipeleers D. Effects of glucose and $3^{\prime}, 5^{\prime}$-cyclic adenosine monophosphate upon reaggregation of single pancreatic B-cells. Endocrinology $19841142205-2209$.

29 Maki LW \& Keizer J. Analysis of possible mechanisms for in vitro oscillations of insulin secretion. American Journal of Physiology 1995268 C780-C791.

30 O'Rahilly S, Turner RC \& Matthews DR. Impaired pulsatile secretion of insulin in relatives of patients with non-insulin-dependent diabetes. New England Journal of Medicine 1988318 1225-1230.

31 Polonsky KS. Lilly Lecture 1994. The beta-cell in diabetes: from molecular genetics to clinical research. Diabetes 199544 705-717.

Received 19 March 1999

Accepted 9 April 1999 